For, Ninth Mediterranean Symposium on Nuclear Medicine and Radiopharmaceuticals, Lemesos, Cyprus, May 13-17, 1999.

\title{
USE OF RHENIUM-188 LIQUID-FILLED BALLOONS FOR INHIBITION OF CORONARY RESTENOSIS AFTER PTCA - A NEW OPPORTUNITY FOR NUCLEAR MEDICINE
}

\author{
F. F. Knapp, Jr. ${ }^{1}$, R. H. Spencer ${ }^{2}$ and M. Stabin ${ }^{3}$
}

${ }^{1}$ Nuclear Medicine Group, Oak Ridge National Laboratory (ORNL), Oak Ridge, TN 37831-6229

${ }^{2}$ Knoxville Cardiovascular Group, University of Tennessee Medical Center, Knoxville, TN 37920

${ }^{3}$ Universiad Federal de Pernambouco, Recife, Brazil

Key Words: arterial restenosis therapy, rhenium-188, liquid-filled angioplasty balloons

* For reprints and correspondence contact: F. F. (Russ) Knapp, Jr., Ph.D., Nuclear Medicine Group, Building 4501, Oak Ridge National Laboratory (ORNL), P.O. Box 2008, Oak Ridge, TN, 37831-6229; Tel. (423) 574-6225; FAX (423) 574-6226; E-mail <jkp@ornl.gov>.

Research at ORNL supported by the Office of Biological and Environmental Research (OBER), U.S. Department of Energy (DOE), under contract DE-AC05-96OR22464 with the Lockheed Martin Energy Research Corporation.

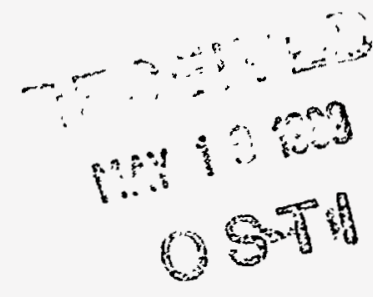




\section{DISCLAIMER}

This report was prepared as an account of work sponsored by an agency of the United States Government. Neither the United States Government nor any agency thereof, nor any of their employees, make any warranty, express or implied, or assumes any legal liability or responsibility for the accuracy, completeness, or usefulness of any information, apparatus, product, or process disclosed, or represents that its use would not infringe privately owned rights. Reference herein to any specific commercial product, process, or service by trade name, trademark, manufacturer, or otherwise does not necessarily constitute or imply its endorsement, recommendation, or favoring by the United States Government or any agency thereof. The views and opinions of authors expressed herein do not necessarily state or reflect those of the United States Government or any agency thereof. 


\section{DISCLAIMER}

Portions of this document may be illegible in electronic image products. Images are produced from the best available original document. 
USE OF RHENIUM-188 LIQUID-FILLFD BALLOONS FOR INHIBITION OF CORONARY RESTENOSIS AFTER PTCA - A NEW OPPORTUNITY FOR NUCLEAR MEDICINE

\author{
F. F. Knapp, Jr. ${ }^{1}$, R. H. Spencer ${ }^{2}$ and M. Stabin ${ }^{3}$ \\ ${ }^{1}$ Nuclear Medicine Group, Oak Ridge National Laboratory (ORNL), Oak Ridge, TN 37831-6229 \\ ${ }^{2}$ Knoxville Cardiovascular Group, University of Tennessee Medical Center, Knoxville, TN 37920 \\ ${ }^{3}$ Universiad Federal de Pernambouco, Recife, Brazil
}

Key Words: arterial restenosis therapy, rhenium-188

\title{
ABSTRACT
}

Although the use of ionizing radiation for the treatment of benign lesions such as keloids has been available for nearly one hundred years, only recently have the cost effective benefits of such technology for the inhibition of arterial restenosis following controlled vessel damage from balloon angioplasty been fully realized. In particular, the use of balloons filled with solutions of beta-emitting radioisotopes for vessel irradiation provide the benefit of uniform vessel irradiation. Use of such contained ("unsealed") sources is expected to represent a new opportunity for nuclear medicine physicians working in conjunction with interventional cardiologists to provide this new approach for restenosis therapy.

\section{THE PROBLEM - RESTENOSIS IN RESPONSE TO VESSEL DAMAGE}

The high incidence of arterial restenosis following percutanous transluminal angioplasty of the coronary (PTCA) and peripheral vessels (PTA) is often an unavoidable consequence of balloon dilatation. Over 900,000 heart attacks are documented in the U.S. annually, and restoration of blood flow by coronary angioplasty is a less expensive procedure then coronary bypass graft surgery. Renarrowing of the following angioplasty is a major clinical problem, even after stent implantation, however, since part of the biological response to this vessel damage is stimulation (accelerated growth) of arterial smooth muscle cells causing neointimal hyperplasia 
(growth). Over 400,000 coronary angioplasty procedures are performed annually in the U.S., and estimates from the American Heart Association indicate a restenosis incidence as high as $30-40 \%$. Restenosis of the peripheral vessels following such procedures is also a common problem. A large patient population could thus benefit from methods which would inhibit the hyperplasia often encountered after the angioplasty procedure.

Although a variety of pharmacological methods are being explored, the use of ionizing radiation (intravascular radiation therapy, or "IRT") has been found to be the most efficient, easily performed procedure, and these methods are expected to be very cost effective for inhibiting arterial restenosis (Waksman, 1999). An alternative approach uses radioactive "stents" for vessel wall irradiation to inhibit restenosis. Catheter-based systems now in clinical evaluation for vessel irradiation after angioplasty include the use small radioactive wires and the use of radioactive solutions for balloon inflation.

\section{USE OF IONIZING RADIATION TO INHIBIT THE HYPERPLASTIC RESPONSE}

The angioplasty procedure involves the "controlled" damage of the vessel wall, and the natural biological response to this injury is the migration of various cell species and factors to the damaged area with the intent of repairing the damage. In some patients the release of growth factors stimulates excessive intimal smooth muscle cell growth at the damaged vessel sites leading to restenosis (Waksman, 1999). The restenotic lesion is morphologically and biochemically different than the original atherosclerotic lesion, and is formed acutely after PTA rather than chronically over a long time period. The use of intraarterial radiation devices to deliver a sufficient dose (for example, 21 Gray at $0.75 \mathrm{~mm}$ depth) to the damaged arterial wall is the most promising method yet established to be successful in preventing intimal hyperplasia. Although the identity of the actual target cell(s) and mechanism of action are not well understood, use of radiation offers the promise as a simple method. Both gamma- and beta particle-emitting radioinuclides as well as $\mathrm{X}$-ray sources are being evaluated for this application. Although most current radioisotopic approaches utilize solid sources, consisting of seeds or coils attached to flexible guide wires or a linear array of radioactive seeds, centering can often be a problem. Theoretically, use of a radioactive solution which would uniformly fill the expanded balloon and 
thus provide the most uniform dose to the vessel wall.

The catheter-based applications use existing equipment familiar to those physicians who currently perform PTCA/PTA. After the angioplasty is completed, a solid source guide or deflated balloon is placed inside the lesion. The radioactive solid or liquid is then transferred into the treatment device for the prescribed time required to deliver the treatment dose. In both extensive animal and several clinical studies, various vehicles for delivering the radioactive source have been evaluated (Waksman, 1999). These approaches include "high dose/high dose rate" systems using solid sources or radioactive solutions. Examples of solid devices include iridium192 wires (a gamma emitting radioisotope), yttrium-90 wires and strontium-90 seeds (beta emitting radioisotopes). The strontium-90 decays to yttrium-90, producing a steady-state concentration of this beta-emitting radioisotope. High energy beta-emitting sources offer an advantage for radiological protection as well as more localized dose delivery. One advantage

Table 1. Examples of Radioisotopes Being Used For Inhibition of Restenosis After PTCA

\begin{tabular}{|l|l|l|l|l|}
\hline $\begin{array}{c}\text { Radionuclide } \\
\text { Emission }\end{array}$ & Half-Life & \multicolumn{1}{|c|}{$\begin{array}{c}\text { Delivery } \\
\text { System }\end{array}$} & $\begin{array}{l}\text { Company/ } \\
\text { Institution }\end{array}$ & \multicolumn{1}{|c|}{ Comments } \\
\hline $\begin{array}{l}\text { Sr-90 Daughter } \\
2.28 \mathrm{MeV} \beta^{-}\end{array}$ & $\begin{array}{l}2.67 \text { Days } \\
\text { Sr-90, 29y }\end{array}$ & $\begin{array}{l}\text { Linear Array } \\
\text { of Particles }\end{array}$ & Novoste & $\begin{array}{l}\text { Clinical Efficacy } \\
\text { Demonstrated - 1996 }\end{array}$ \\
\hline $\begin{array}{l}\text { Iridium-192 } \\
\text { 360 keV }\end{array}$ & 73.4 Days & Wire & $\begin{array}{l}\text { Guidant, Vascular } \\
\text { Therapies }\end{array}$ & $\begin{array}{l}\text { Clinical Efficacy Demonstrated 1996; } \\
\text { Effective with Popliteal /Femoral }\end{array}$ \\
\hline $\begin{array}{l}\text { Phosphorus-32 } \\
1.709 \mathrm{MeV} \beta^{-}\end{array}$ & 14.3 Days & $\begin{array}{l}\text { Ion Implanted } \\
\text { Stent }\end{array}$ & Isostent, Inc. & Effective in Animal Models \\
\hline $\begin{array}{l}\text { Vanadium-48 } \\
0.95 \mathrm{MeV} \beta^{+}\end{array}$ & 16 Days & $\begin{array}{l}\text { lon Implanted } \\
\text { Stent }\end{array}$ & $\begin{array}{l}\text { Cedars Sinai, Los } \\
\text { Angeles }\end{array}$ & Effective in Rabbit Studies \\
\hline $\begin{array}{l}\text { Rhenium-186 } \\
1.071 \mathrm{MeV} \beta^{-}\end{array}$ & 3.78 Days & $\begin{array}{l}\text { Solution for } \\
\text { Balloon Inflation }\end{array}$ & Mallinckrodt & $\begin{array}{l}\text { Reactor-Produced; Perrhenate Has } \\
\text { Rapid Urinary Excretion }\end{array}$ \\
\hline $\begin{array}{l}\text { Rhenium-188 } \\
2.1 \mathrm{MeV} \beta^{-}\end{array}$ & 16.9 Hours & $\begin{array}{l}\text { Solution for } \\
\text { Balloon Inflation }\end{array}$ & $\begin{array}{l}\text { ORNL, Guidant, } \\
\text { Vasuclar Therapies }\end{array}$ & $\begin{array}{l}\text { Available On-Demand from } \\
\text { Tungsten-188 Generator Having } \\
\text { Useful Shelf-Life of Several Months; } \\
\text { Rapid urinary excretion }\end{array}$ \\
\hline
\end{tabular}

of the technique using linear sources is that irradiation proceeds for periods up to 20 minutes, since coronary flow is preserved. A potentially significant disadvantage is that centering of the 
source in the lumen can be a problem, especially in large and tortuous vessels, providing nonuniform irradiation. Research has indicated that under dosing can actually stimulate the hyperplastic process.

The "low dose rate" approach uses permanently-implanted radioactive metal stent supports, radiolabeled with isotopes such as phosphorus-32, vanadium-48, and more recently, rhenium-188 and palladium-103. The use of radioactive stents is an alternative procedure which provide low dose-rate radiation for many days after implantation. They require limited occupational exposure safeguards. One disadvantage may be the logistics and maintenance of an adequate inventory of the radioactive stents, since radioisotopes used for this application have relatively short half-lives.. Also, the results of some studies with radioactive stents suggest that lower dose rates near the end of the decay cycle of the radioisotopes may stimulate tissue growth.

\section{ADVANTAGES OF USING BALLOONS FILLED WITH SOLUTIONS OF BETA- EMITTING RADIOISOTOPES FOR RESTENOSIS THERAPY}

The use of solutions of high energy beta-emitting radioisotopes provides several advantages, which include localized and uniform dose delivery and more simple radiation protection issues that minimize exposure to the patient and operator. Another advantage is that this approach delivers the most uniform vessel wall irradiation since the balloon is inherently centered in the vessel. Examples of beta-emitting radioisotopes which have been evaluated for this unique liquid-filled balloon approach for vessel irradiation (Table 2) include rhenium-188 (Knapp, et al., 1998a, 1999), rhenium-186 (Robinson, et al., 1998, 1999), holmium-166 (Kim, et al., 1998) and phosphorus-32 (Khan, et al., 1996).

This catheter-based approach using balloons filled with beta-emitting radioisotope liquids involves threading a small deflated balloon through the catheter for placement in the coronary artery region of interest following the angioplasty procedure. Since this procedure involves the use of unsealed sources, either a nuclear medicine physician and/or a nuclear cardiologist would be expected to be responsible for balloon inflation, depending on the country and institutional and regulatory requirements. Care and precautions must be taken in the unlikely event of liquid 
leakage (i.e. $<1 / 10,000$ ) either within the vessel or on the table. The dose is delivered at low pressure with a radioactive solution for short time periods (Eigler, et al., 1998, 1999), or in principle, for longer time periods with a perfusion balloon system (Weinberger, et al., 1999), thus minimizing any risk of balloon failure that could occur at higher inflation pressures. Although uniform dose delivery and more controlled radiation protection are important advantages, the dose planning must be more accurately planned, because of the rapid fall-off of dose with radial distance.

Table 2. Examples of Trials With Catheter-Based Systems Using Angioplasty Balloons Filled with Beta-Emitting Radioisotopes for Vascular Radiation Therapy

\begin{tabular}{|c|c|c|c|c|}
\hline Radioisotope & $\begin{array}{l}\text { Hal-Life } \\
\text { Beta, } E_{\max }\end{array}$ & Availability & $\begin{array}{l}\text { Trial Designation } \\
\text { Sponsor/nstitution }\end{array}$ & Comment \\
\hline Holmium-166 & $\begin{array}{l}23 \text { Hours } \\
1.7 \mathrm{MeV}\end{array}$ & $\begin{array}{l}\text { Reactor } \\
\text { Produced }\end{array}$ & Seoul, Korea & $\begin{array}{l}\text { Bone Seeker - } \\
\text { Probably should be } \\
\text { complexed }\end{array}$ \\
\hline Phosphorus-32 & $\begin{array}{l}14.3 \text { days } \\
1.71 \mathrm{MeV}\end{array}$ & $\begin{array}{l}\text { Reactor } \\
\text { Produced }\end{array}$ & $\begin{array}{l}\text { Baylor College of Medicine, } \\
\text { Houston }\end{array}$ & $\begin{array}{l}\text { Only animal studies } \\
\text { reported }\end{array}$ \\
\hline Rhenium-188 & $\begin{array}{l}\text { 16.9 Hours } \\
2.12 \mathrm{MeV}\end{array}$ & $\begin{array}{l}\text { From } \\
\text { W-188/Re-188 } \\
\text { Generator }\end{array}$ & $\begin{array}{l}\text { U.S. Surgical "RADIANT" - Trials } \\
\text { Cedars Sinai Medical Center, } \\
\text { Los Angeles; } \\
\text { Munich, Germany } \\
\text { Guidant Corporation } \\
\text { "CURE" - Columbia University } \\
\text { "VOLS" - Guidant/Univ. Tenn. }\end{array}$ & $\begin{array}{l}\text { Extensive data for } \\
\text { swine coronary } \\
\text { overstretch and stent } \\
\text { injury model - Several } \\
\text { animal and clinical } \\
\text { protocols in progress }\end{array}$ \\
\hline Rhenium-186 & $\begin{array}{l}90.6 \text { hours } \\
1.08 \mathrm{MeV}\end{array}$ & $\begin{array}{l}\text { Reactor } \\
\text { Produced }\end{array}$ & Mallinckordt Medical & $\begin{array}{l}\text { Clinical studies being } \\
\text { initiated }\end{array}$ \\
\hline
\end{tabular}

\section{USE OF RHENIUM-188 LIQUID-FILLED BALLOONS FOR RESTENOSIS THERAPY}

We propose the use of the liquid-filled balloons using rhenium-188 (16.9 hour half-life, 2.1 MeV maximal beta energy) as an excellent new candidate for use as an intravascular radiation source for uniform vessel wall irradiation (Knapp, et al., 1997a, 1997b, 1998a, 1998b), and most studies to date in both animal models and human trials have used this radioisotope. Rhenium-188 is an attractive radioisotope for this application since it is conveniently obtained from the tungsten188/rhenium-188 generator (Figures 1 and 2). Because of the long useful generator shelf-life (i.e. 
3-6 months), high daily elution yields ( $>60 \%$ ), and chemistry similar to pertechnetate, rhenium188 is a cost effective radioisotope for restenosis therapy (Knapp, et al., 1997b, 1999). The high beta energy (2.12 MeV), uniform dose delivery and rapid urinary excretion of various rhenium-188 species such as perrhenate (Knapp, et al., 1999; Hausleiter, et al., 1999; Kotzerke, et al., 1998), Re(M)-MAG3 (Knapp, et al., 1999) and Re(V)-DTPA (Hsieh, et al., 1999; Lee, et al., 1998), make these rhenium-188-labeled agents excellent new candidates for catheter-based vessel irradiation following PTCA. In addition, we have developed a personal computer-based software system using Monte Carlo simulations for the dose planning which is an important aspect of this strategy for restenosis therapy (Stabin, et al., 1998).

The rhenium-188 radioisotope is conveniently obtained from the tungsten-188/rhenium188 generator which is fabricated from reactor-produced tungsten-188. As the tungsten-188 decays, it continuously forms the rhenium- 188 daughter radioisotope, which can be removed from the generator by passing through a saline solution. The daily availability of radioisotopes for restenosis therapy is very important since arterial dilatation, stent placement and subsequent irradiation are frequently conducted on an acute basis. Thus, the radioisotope for treatment must be available on short notice from inventory or from a radiopharmacy.

High specific volume solutions of rhenium-188 $(130-200 \mathrm{mCi} / \mathrm{mL})$ are required for this application because of the small balloon volumes and requirement of minimal inflation periods to reduce total treatment times to prevent tissue ischemia ("dwell time"). The relatively low specific volume solutions of thenium-188 which are obtained from the tungsten-188/rhenium-188 generator (Knapp, et al., 1998) are easily and rapidly concentrated to high specific volumes using the simple tandem column concentration technology (Guhlke, et al., 1997); Knapp, et al., 1998b) (Figure 3).

Swine studies using a coronary balloon overstretch model have validated the expected effectiveness of the rhenium-188 liquid-filled balloon approach for inhibition of coronary restenosis (Giedd, et al., 1997) (Figure 4) and stent injury (Eigler, et al., 1998 and 1999). In addition, the unlikely release of activity from balloon rupture has been evaluated extensively in rats (Knapp, et al., 1999), swine (Hausleiter, et al, 1999) and in preliminary human studies (Kotzerke, et al, 1998). These studies have demonstrated that the organ adsorbed dose consequences of release of the 
levels of rhenium-188 required for vessel irradiation $(30-50 \mathrm{mCi})$ do not result in any excessive target organ dose, since the various chemical species are rapidly excreted via the urinary bladder and thyroid uptake is easily blocked or displaced with oral perchlorate (Knapp, et al., 1999; Hausleiter, et al, 1999; Kotzerke, et al, 1998)

Finally, recent results of initial feasibility clinical trials evaluating the rhenium- 188 liquid-filled balloon approach have demonstrated the effectiveness of this technique to significantly reduce the incidence of coronary restenosis following PTCA in both native and "in stent" restenotic lesions (Eigler, et al., 1999; Weinberger, et al., 1999)

\section{A NEW WINDOWS-BASED COMPUTER CODE PROVIDES A USEFUL TOOL FOR COMPARISON OF DOSE DELIVERY AND FOR DOSE PLANNING}

The importance of accurate dose planning for intravascular radiation therapy requires the availability of an easily accessible computer-based system for dose estimation, which can take into account the emissions of the radioisotope, vessel diameter and other variables. The recent program developed by Stabin, et al. (1998) represents a readily accessible interactive computer program which calculates both electron and photon doses to the walls of blood vessels for a large number of radionuclides in the MIRD table and discrete energies, in several geometries using both MCNP 4B and EGS4 Monte Carlo computer codes. For a given energy, radionuclide, and vessel diameter, the radiation dose is calculated using a Windows-based personal computer code, applicable to both centered sources and liquid-filled balloons. The model design includes the presence of atherosclerotic plaque, modeling of balloon structural guidewires and guidewire tube, and the use of contrast material (Isovue 370 ) in the balloon contents. Results for the discrete energy sources have been also incorporated into a Windows-based personal computer program which permits the easy selection of radionuclides and irradiation geometries and the rapid reporting of results. Use of this program allows a quick comparison of wire and balloon-type sources, gamma emitter's versus beta-emitters, etc., in vessels of different sizes, and will be further developed as a dose planning system. This current program allows the rapid evaluation of different radionuclides and irradiation geometries for use in this important new technology. An example of the results of using this code is illustrated in Figure 5. 
The computer code is available on the Internet for download by accessing the ftp site at the Oak Ridge Associated Universities (ORAU), in Oak Ridge, Tennessee, U.S.A. at <ftp@orau.gov>. Instructions for downloading this software can be obtained by contacting Michael Stabin, Ph.D., CHP, Departamento de Energia Nuclear/UFPE, Av. Prof. Luiz Freire, 1000, Citade Universitaria, Recife - PE, Brazil; E-mail <stabin@npd.ufpe.br>.

\section{SUMMARY AND CONCLUSIONS}

The widespread use of radioactive balloons filled with beta-emitting radioisotopes is expected to represent a new opportunity for nuclear medicine physicians to work in a partnership with interventional cardiologists and medical physicists in providing an effective method for vascular restenosis therapy. This combination of an efficient and cost-effective radionuclide delivery and concentration system in combination with dose planning capability make the rhenium188-liquid-filled balloon an important candidate for restenosis therapy of the coronary and peripheral arteries.

\section{ACKNOWLEDGMENTS}

Research at ORNL is sponsored by the Office of Biological and Environmental Research (OBER) U.S. Department of Energy (DOE), under contract AC05-960R22464 with Lockheed Martin Energy Research Corporation

\section{REFERENCES}

EIGLER N, WHITING J, MAKKAR R, et al. "The Radiant liquid radioisotope intravascular radiation therapy system" In, Proceedings, Advances in Cardiovascular Radiation Therapy III, Renaissance Hotel, Washington, D.C., February 17-19, 1999, pp. 391-397.. 
EIGLER N, WHITING J, MAKKAR R, et al. Radiant liquid isotope intravascular radiation therapy system," In, Proceedings, Advances in Cardiovascular Radiation Therapy II, Renaissance Hotel, Washington, D.C., March 8-10, 1998, pp.234-237.

GIEDD, K. N., AMOLS, H., MARBOE, C., et al. "Effectiveness of beta-emitting liquid-filled perfusion balloon to prevent restenosis," Circulation 96 (1997) I-220.

GUHLKE S, BEETS AL, KNAPP FF JR, et al. "Elution of Re-188 from W-188/Re-188 generators with salts of weak acids permits efficient concentration to low volumes using a new tandem action/anion exchange system," J. Nucl. Med. 38 (1997) 125P.

HAUSLEITER J, LI A, KNAPP FF JR, et al. "Low body exposure in case of radioactive balloon leakage - a biodistribution and elimination study of 188 rhenium in pigs," J. Amer. Coll. Card., 33 (Supplment A) (1999) 44A.

HSIEH BT, LIN WY, WANG SJ, et al. "A new potential radiopharmaceutical for intravascular radiation therapy," In, Proceedings, Third Annual Symposium on radiotherapy to reduce restenosis," Scripps Institute, La Jolla, CA, January 15-16, 1999.

KHAN M, ALI NM, MAZUR W, et al. "A novel method to deliver intra-arterial $\beta$-radiation for prevention of restenosis in the porcine model," Cathet. Cardiovasc. Diagn. 38 (1996) 117.

KIM HS, CHO YH, OH YT, et al. "Effect of transcatheter endovascular holmium-166 irradiation on neointimal formation after balloon injury in porcine coronary artery," J. Am. Coll. Cardiol. 31 (Supplement A) (1998) 277A.

KNAPP FF JR, BEETS AL, GUHLKE $S$, et al. "Availability of rhenium-188 from the aluminabased tungsten-188/rhenium-188 generator for preparation of rhenium-188-labeled radiopharmaceuticals for cancer treatment," Anticancer Res. 17 (1997a) 1783-1796. 
KNAPP FF JR, GUHLKE S, BEETS AL, et al. "Rhenium-188 - attractive properties for introvascular brachytherapy for inhibition of coronary restenosis after PTCA" J. Nucl. Cardiol. 4 (1997b) S-118.

KNAPP FF JR, BEETS AL, MIRZADEH S., et al. "Use of a new tandem cation/anion exchange system with clinical-scale generators provides high specific volume solutions of technetium- $99 \mathrm{~m}$ and rhenium-188," In, IAEA -TECDOC-1029, pp. 419-425 (1998a).

KNAPP FF JR, BEETS AL, GUHLKE S, et al. "Rhenium-188 liquid-filled balloons effectively inhibit restenosis in a swine coronary overstretch model - a simple new method bridging nuclear medicine and interventional cardiology," J. Nucl. Med. 39 (1998b) 48P.

KNAPP FF JR, GUHLKE S, BEETS AL, et al. "Endovascular beta irradiation for prevention of restenosis using solution radioisotopes: pharmacologic and dosimetric properties of rhenium-188 compounds," Cardiovasc. Rad. Med. 1 (1999) 1-12.

KOTZERKE J, FENCHEL S, GUHLMANN A, et al. "Pharmacokientics of ${ }^{99 m}$ Tc-pertechentate and ${ }^{188}$ Re-perrhenate after oral administration of perchlorate: option for subsequent care after the use of liquid ${ }^{188}$ Re in a balloon catheter," Nucl. Med. Commun. 19 (1998) 795-801.

LEE J, LEE DS, JEONG JM, et al. "Dosimetry and MIRD of Re-188-DTPA for endovascular balloon brachytherapy against restenosis after coronary angioplasty: comparison with Re-188perrhenate," Eur. J. Nucl. Med. 25 (1998b) 1137.

ROBINSON K, PIPES DW, VON BIBBER R, et al. "186 Re-Liquid-filled balloon catheter system for endovascular brachytherapy: dose-response efficacy study and biodistribution after coronary injection," Circulation Suppl. I (1998) 3432.

ROBINSON K, PIPES DW, VAN BIBBER $R$, et al. " $\beta$-Emitting Rhenium-186 liquid-filled balloon catheter for endovascular irradiation to prevent restenosis: safety and efficacy preclinical studies," J. Amer. Coll. Card., 33 (Supplment A) (1999) 43A. 
STABIN M, KONIJNENBERG M, KNAPP FF JR, et al. "Interactive computer program for calculation of radiation dose to the walls of blood vessels in intravascular radiation therapy," In, Proceedings, Advances in Cardiovascular Radiation Therapy II, Renaissance Hotel, Washington, D.C., March 8-10, 1998, p. 28..

WAKSMAN R, Editor, Vascular Brachytherapy, Futura Publishing Co., Armonk, New York, 1999 (ISBN\#: 0-87993-4131), 630 pages.

WEINBERGER J, AMOLS HI, SCHIFF B, et al. "Initial results of the CURE safety trial: coronary brachytherapy with radioactive liquid-filled balloons," J. Amer. Coll. Card., 33 (Supplment A) (1999) $94 \mathrm{~A}$. 
FIGURE LEGENDS

Figure 1. Schematic of the tungsten-188/rhenium-188 generator and tandem concentration system.

Figure 2. Photograph of a cut-away lead shield showing the tungsten-188/rhenium-188 generator housed in a Lucite liner in the lead shield. The Lucite liner effectively minimizes the Bremmstrahlung radiation from the beta particles interacting with the lead shield.

Figure 3. Illustration of the large volume in the elution syringe required for elution of the rhenium-188 bolus in comparison to the final concentrated solution filling an angioplasty balloon.

Figure 4. Illustration of the effectiveness of use of the use of rhenium-188 liquid-filled balloon inhibiting smooth muscle cell proliferation in a swine model. The left panel illustrates the cross section of a swine coronary artery 30 days after balloon overstretch injury. The right panel illustrates another arterial segment obtained from the same swine 30 days after receiving a dose of 25 Gray at a depth of 0.5 $\mathrm{mm}$ at the overstretch injury site (Courtesy of J. Weinberger, M.D., Ph.D., Columbia University).

Figure 5. Illustration of Monte Carlo code developed by M. Stabin. Ph.D., to estimate the radiation dose delivered as a function of radial distance from the lumen wall for various beta energies. 


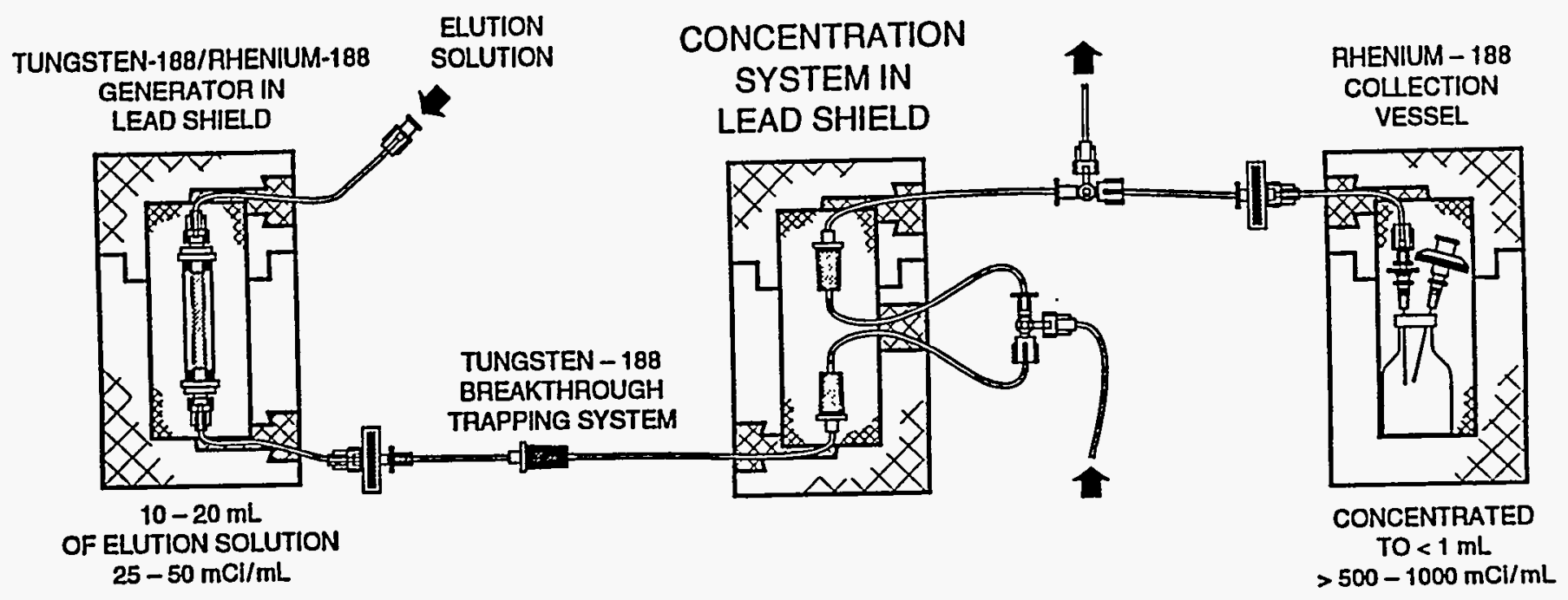

Figure 1. Schematic of the tungsten-188/rhenium-188 generator and tandem concentration

Figure 1. Schematic of the tungsten-188/rhenium-188 generator and tandem concentration
system.

$0 \quad 12$ INCHES

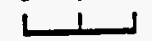




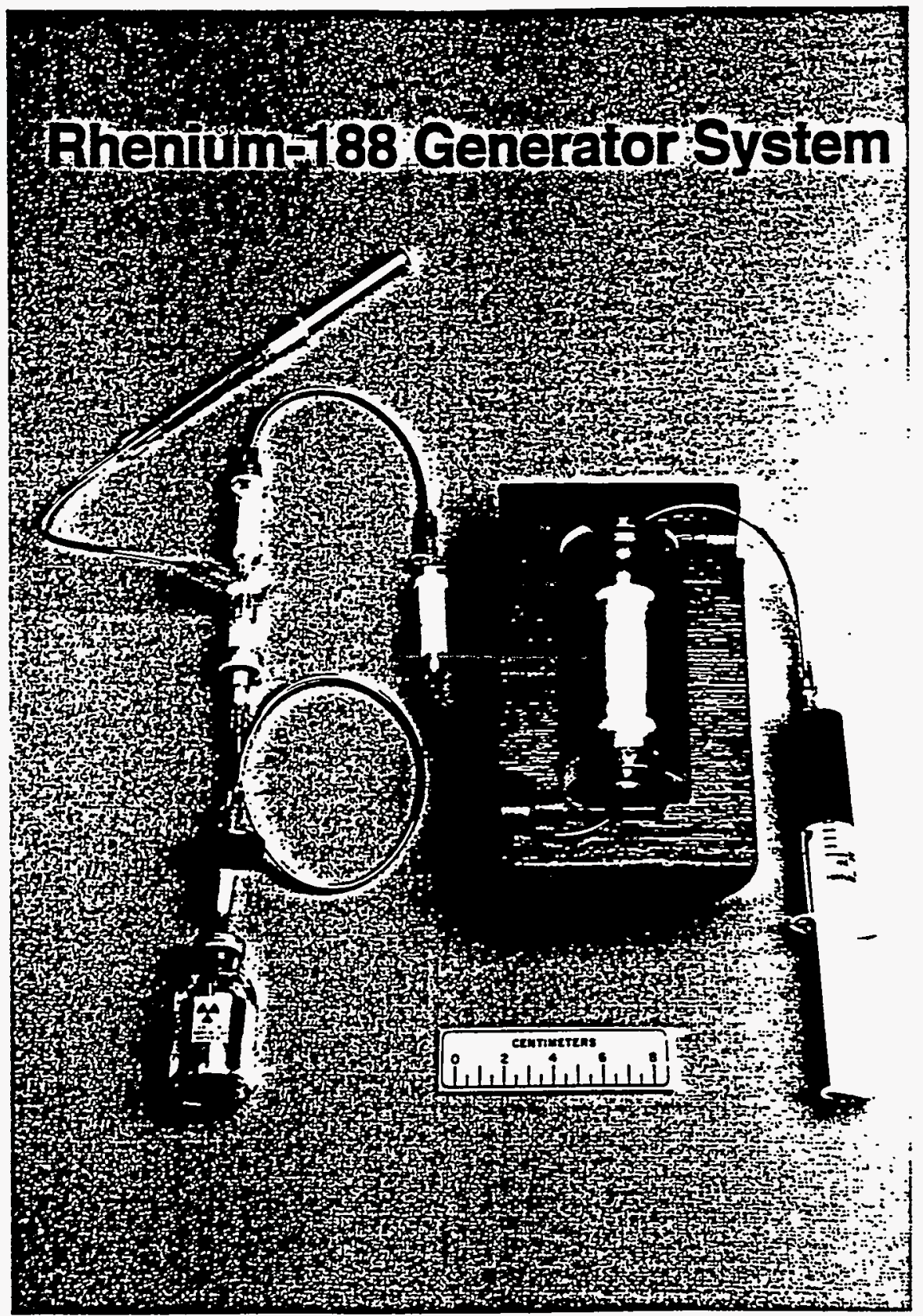

Figure 2. Photograph of a cut-away lead shield showing the tungsten-188/rhenium-188 generator housed in a Lucite liner in the lead shield. The Lucite liner effectively minimizes the Bremmstrahlung radiation from the beta particles interacting with the lead shield. 


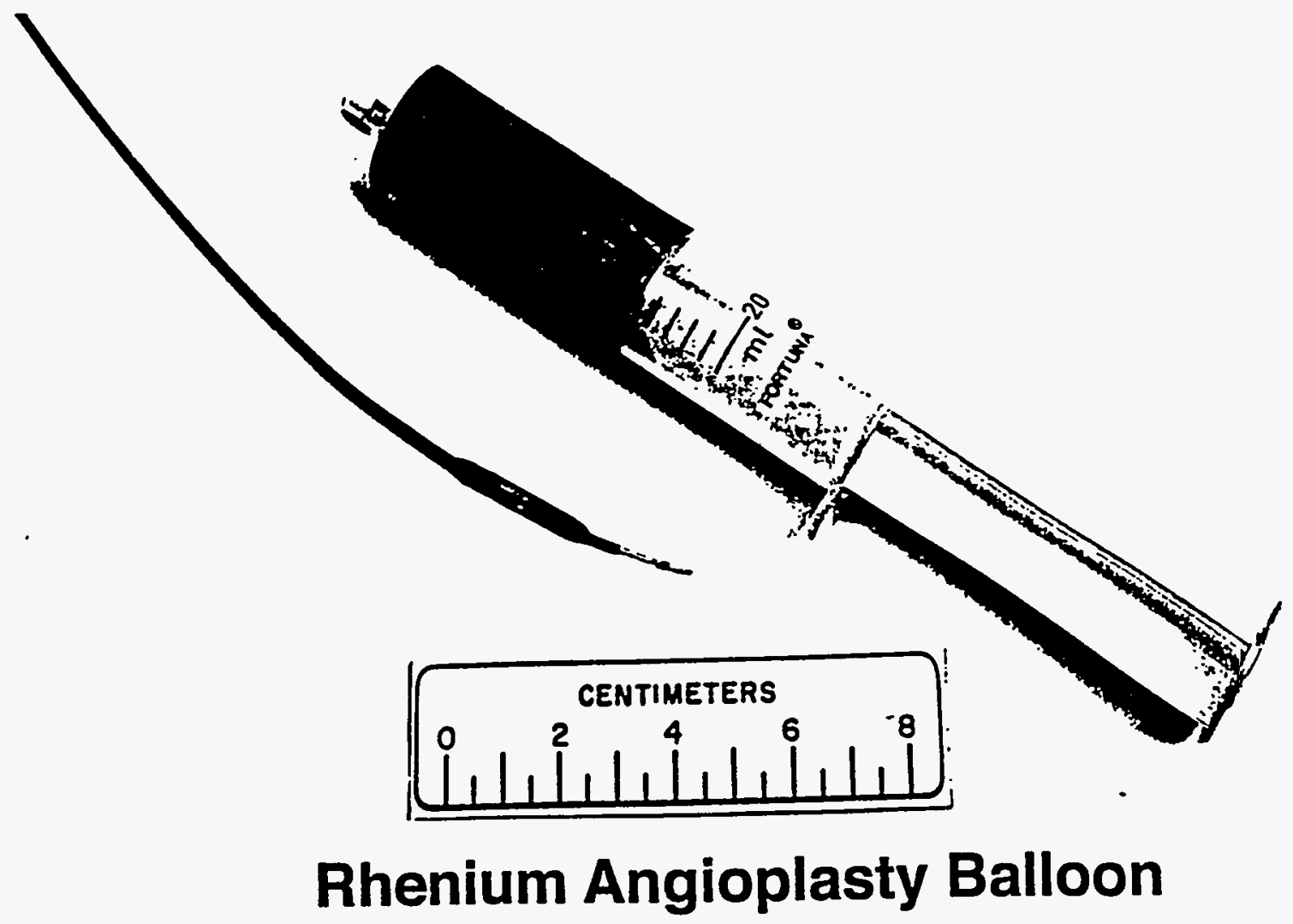

Figure 3. Illustration of the large volume in the elution syringe required for elution of the rhenium-188 bolus in comparison to the final concentrated solution filling an angioplasty balloon. 


\section{Inhibition of Restenosis with Rhenium-188 has been Demonstated in a Swine Coronary Balloon Overstretch Injury Model}

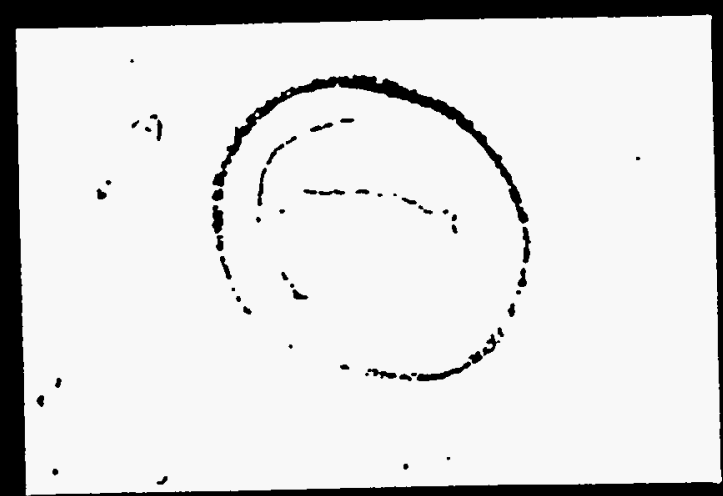

Control artery 30 days after balloọn overstruetch injụry

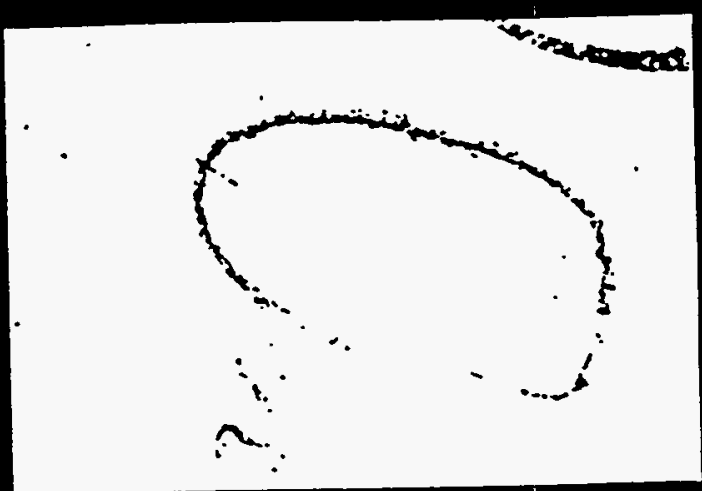

Injured artery 30 days following 25 Gray Poṣe from Rhenium-1898

(Daţa from Juḍah Weing.̣erger, M.P. Ph.P., Columbia University, New York)

Figure 4. Illustration of the effectiveness of use of the use of rhenium-188 liquid-filled balloon inhibiting smooth muscle cell proliferation in a swine model. The left panel illustrates the cross section of a swine coronary artery 30 days after balloon overstretch injury. The right panel illustrates another arterial segment obtained from the same swine 30 days after receiving a dose of 25 Gray at a depth of 0.5 $\mathrm{mm}$ at the overstretch injury site (Courtesy of J. Weinberger, M.D., Ph.D., Columbia University). 


\section{$4 \mathrm{~mm}$ Diameter Vessel}

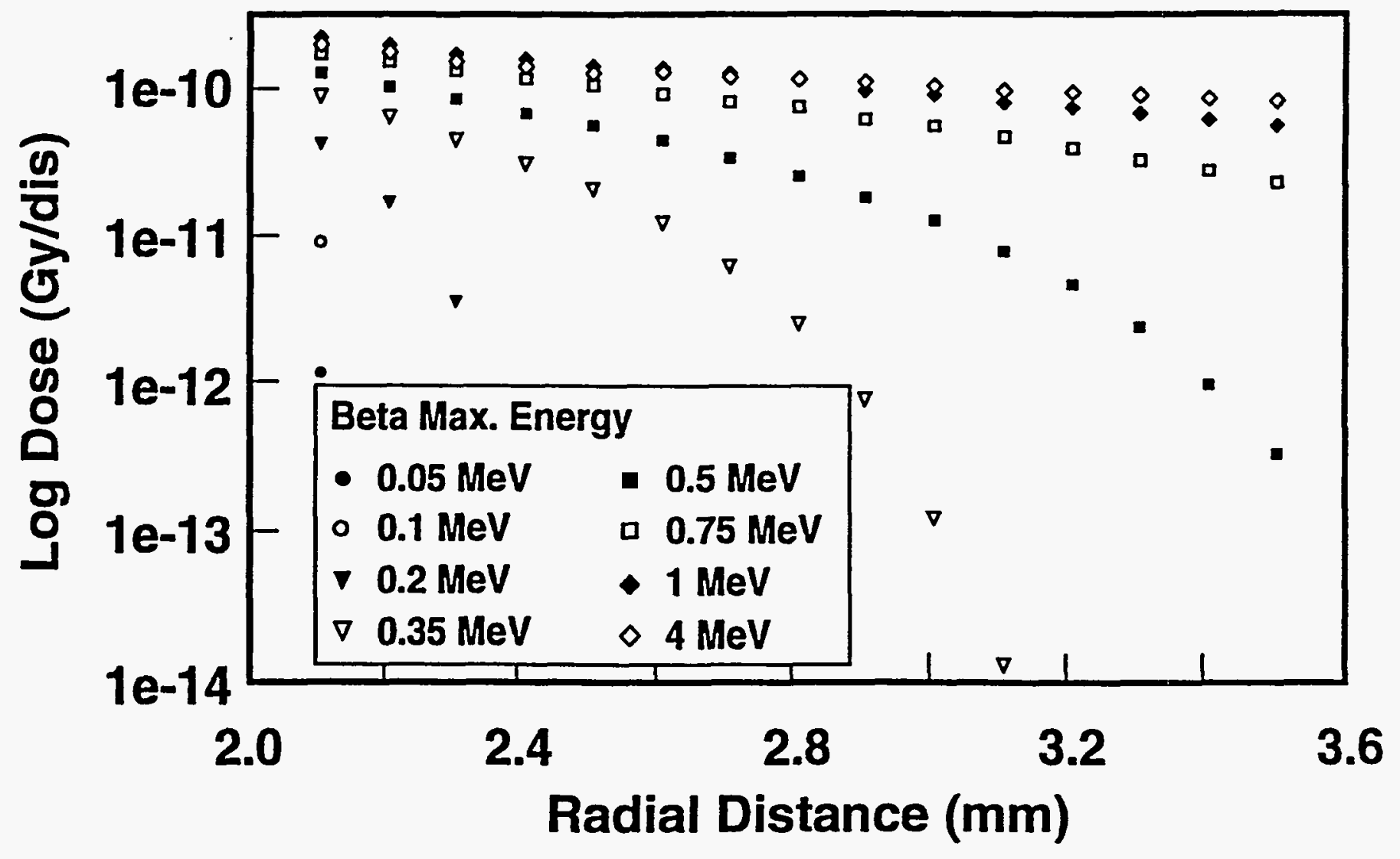

Figure 5. Illustration of Monte Carlo code developed by M. Stabin. Ph.D., to estimate the radiation dose delivered as a function of radial distance from the lumen wall for various beta energies. 